\title{
SOME EXPRESSIONS OF AFRICAN HOSPITALITY TODAY
}

\author{
Julius Mutugi Gathogo ${ }^{1}$ \\ School of Religion and Theology \\ University of KwaZulu-Natal
}

\begin{abstract}
The paper sets out to demonstrate that any emerging post Cold War theology, in Africa, ought to underline the concept of hospitality as it is not only an inherently African conception but more importantly, it is both a reconstructive and reconciliative element in the Africa of the 21 st century. In particular, it is critical to include hospitality into the theological schema of reconstruction. To do this, it has attempted a survey on the socio-religious expressions of African hospitality - as it shows its relevance in our modern day African theological articulation.
\end{abstract}

Key words: African Hospitality, Interdependence, Proverbs, Reconstruction, Ubuntu

Africans believe in something that is difficult to render in English. We call it 'ubuntu, botho'. It means the essence of being human. You know when it is there and when it is absent. It speaks about humaneness, gentleness, and hospitality, putting yourself on behalf of others, being vulnerable. It embraces compassion and toughness. It recognizes that my humanity is bound up in yours, for we can only be human together.

- Archbishop Desmond Tutu

\section{Introduction}

The subject under discussion in this paper is an ambitious one; and as such, I cannot and do not mean to satisfy it. Nevertheless, I do wish to highlight some socio-religious manifestations of African hospitality without claiming to be exhaustive. From this I hope to offer a survey of this very important aspect of African culture that, I believe, has not been given adequate attention in African Christian theology, as in the case of African religion - yet they both permeate into all sectors of life "so fully that it is not easy or possible always to isolate it." As John Mbiti says of ancient African religiosity, it is difficult to give a formal distinction between its sacred and its secular dimension; the same can be said of elemental African hospitality. ${ }^{4}$ For in my view, whenever an ancient African man or woman goes, he or she carries his or her hospitality and naturally displays it in the fields, in the ceremonies and in all religio-social gatherings. And even though this ancient hospitality cannot remain intact, it is by no means extinct.

In view of this, the paper sets out to show the socio-religious manifestations of the ancient African hospitality - whose definition is an ambitious one - as it goes beyond catering and kind reception of guests in one's homestead. In other words, how does African

\footnotetext{
Dr Julius Mutugi Gathogo is a Post Doctoral Research Fellow at the School of Religion and Theology, University of KwaZulu-Natal, Pietermaritzburg, South Africa. E-mail: jgathogom@yahoo.com

N Tutu, The words of Desmond Tutu. (London: Hodder and Stoughton, 1989), 69.

JS Mbiti, African Religions and Philosophy. (Nairobi: EAEP, 1969), 1.

JS Mbiti, African Religions and Philosophy: 2.
} 
hospitality in post Cold War Africa manifest itself? How is it visible in the economic, social and religious domains? Is it still intact; and how relevant is it in the modern world? Consequently, the paper starts on the premise that despite 'modernity' African hospitality has something that it can bequeath to the rest of the world. The material in this article is drawn from both library research and field research where certain individuals were consulted.

\section{Hospitality and Interdependence}

African hospitality is grounded on the fact that no one is an island on himself or herself; rather, each and everyone is part of the whole community. This aspect of culture, which was initially pre-literate, pre-scientific and pre-industrial, was originally expressed in the songs and stories, the customs and the institutions of the people. In practical terms therefore, African hospitality expresses the African sense of communality. That is, instead of, "I think, therefore, I exist" (cogito ergo sum) of the French Philosopher Rene Descartes, the African asserts "I am because we are," or "I am related, therefore, I am" (cognatus ergo sum). ${ }^{5}$ This compares with Mbiti's summary of the philosophy underlying the African way of life, thus: "I am, because we are; and since we are, therefore I am." would say, "I belong by blood relationship; therefore I am." Indeed, this parallels with the concretisation of the Being (Sein) as Being-with in the 'Dasein' Analytic in Martin Heidegger's Philosophy of Being. ${ }^{8}$

This foundational background from which African hospitality is built places more emphasis on interdependence. It agrees with Pauline theology on the need to recognise other people's gifts and talents in order to edify the church and the society in general (see Ephesians 4:10-12, 1 Corinthian 12).

Many African proverbs express this communalistic approach to life. To use a Kikuyu (read African) proverb: Mugogo umwe nduaraga iriuko which says: "One log does not make a bridge." It means, on one's own, as an individual, one cannot do something substantial. One needs others for advice, teaching, rebuke, correcting and training above other things (cf. 2 Timothy 3:16). Since bridges help people to cross over the river, and do businesses such as trading and general interactions, one log (read one person) cannot, without teaming up with the others, ensure the continuity of the life of the community; for by relying on oneself, people may starve or be separated for lack of a good bridge to make them pass over and meet one another. Thus, one cannot advise oneself; nor can one rebuke one's own wrongs or correct or train oneself; no one can see his or her back. Indeed, a log needs other logs to combine and make a firm bridge to ensure safety in order for us to cross over the valleys of life together.

Another Kikuyu proverb that expresses the value of interdependence is Indo nikurimithania, saying: "Wealth comes by working together." It means that for a society to prosper, co-operation and mutual support are keys to success. This co-operation is to start from a house/family, clan, and tribe to the whole nation. It agrees with Christ's caution that a house divided cannot stand (Matthew 12:25). To acquire wealth and thereby improve the nation's economic well-being calls for genuine hard work in a co-operative atmosphere.

\footnotetext{
Cf. Julius Gathogo, The Truth About African Hospitality: Is there hope for Africa? (Mombasa: The Salt, 2001), 21.

John S Mbiti, African Religions and Philosophy: 108.

J Healey and D Sybertz, Towards an African Narrative Theology (Nairobi: Paulines, 1996), 62.

M Heidegger, Sein und Zeit, Marx Niemeyer Verlag Türbingen (Siebzehnte Auflage, 1993), 117-125.
} 
The clearest expression of African hospitality in terms of interdependence is found in a Kikuyu proverb that says Gutiri gitatuirie kingi, meaning: "All things are interdependent." The original translation should have been, "no one can dare live without support from another person as success can not be assured." It means that in the society of men and women, every one's contribution is important and necessary. It agrees with St. Paul when he says:

He who descended is the very one who ascended higher than all the heavens, in order to fill the whole universe. It was he who gave some to be apostles, some to be prophets, some to be evangelists, and some to be pastors and teachers to prepare God's people for works of service, so that the body of Christ may be built up until we all reach unity in the

faith... and become mature, attaining to the whole measure of the fullness of Christ

(Ephesians 4:10-14).

An exegesis on this will show that St. Paul contends that for the house of Christ to be properly built, it has to be erected by unity in diversity. That is, the different gifts will have to come in play, some as evangelists, others as prophets, others as pastors, others as teachers, others as administrators, others as singers and in every other way. For the church to be the way it was meant to be, all talents need to be seen as assets that will need to be given room to nourish the church and therefore edify it as St. Paul advised (1 Corinthians 12-14).

Another proverb, which explains the value of interdependence in African hospitality is Iri murungu igiritagia iri kahia, saying: "The hornless animal leans on the one that has them." This Kikuyu proverb can be compared with what the New Testament implies by fellowship among the believers in Christ. The hornless animal can refer to somebody who is a doctor but he or she is not trained as a teacher and also, cannot teach his children and therefore, even though his/her profession is noble, he or she needs the services of a teacher and vice-versa.

The theme of interdependence is so crucial in African cultural hospitality such that even in animal stories, some have been personified and thereby showing their value in African hospitality. The story below about a bird and animals will seek to demonstrate how human beings cannot afford to isolate themselves from one another; as it is costly, risky and unwise.

In the Mwea plains of Kirinyaga District, in Kenya, where I come from, there is a small spotted bird, which is often seen where cows are grazing. The locals have given it different names. Some call it Ndeithi - meaning "the one who shepherds." Others call it Nyange meaning the brown or "the white one who moves here and there." It can also mean "the beautiful one." Others call it Ndieri, which is a meaningless word when translated from the local language - the Kikuyu. These many names show the many roles that this bird plays; plus its importance in educating humans on the theme of interdependence. Interestingly, this bird follows the grazing cattle as if it were the Shepherd and the reason for doing this is that as the cattle move in the grazing land, grasshoppers and other nutritious insects are disturbed and exposed. This in turn offers the bird the opportunity to feast on them easily.

This analogy illustrates that both the cattle and the bird need one another in that the bird helps to remove the ticks that cling to the body of the cow to suck its blood, with the danger of infecting the animal with East Coast Fever and other diseases; at the same time the bird depends on the cow, who exposes insects from their hiding places and thereby giving the Bird a chance to feast on them.

This example of symbiotic behaviour clearly expresses the ideal African hospitality where we see one another as possible assets at all times. It agrees with St. Paul who echoes 
Christ when he says that the body is a unit of many parts which need one another at all times. He says: for "the body is not made up of one part but of many. If the foot should say, 'Because I am not a hand, I do not belong to the body', it would not for that reason cease to be part of the body... If the whole body were an eye where would the sense of hearing be? If the whole body were an ear, where would the sense of smell be? But in fact, God has arranged the parts in the body, every one of them, just as he wanted them to be..." (1 Corinthian 12:12-26).

Arguing on the value of interdependence, the retired Archbishop Desmond Tutu says:

In our African language we say, 'a person is a person through other persons'. I would not know how to be a human being at all except (that) I learned this from other human beings. We are made for a delicate network of relationships, of interdependence. We are meant to complement each other. All kinds of things go horribly wrong when we break that fundamental Law of our being. Not even the most powerful nation can be completely self-sufficient. ${ }^{9}$

African hospitality is thus characterised by the emphasis on interdependence. It is in agreement with Pauline theology, which is echoed from Christology, especially on the assertion that we are one body, one people of God - despite the many different gifts, and talents that are bestowed upon each and every one of us by God - our maker. This calls us to share whatever talents and gifts we have for the sake of God and the general prosperity of our society as away of encouraging one another. For as Hebrew 10:25 says, we ought to encourage one another for the Day of Lord is coming.

\section{Socio-Religious Expressions of African Hospitality}

African hospitality best expresses itself in three ways: Religious Life

Firstly, African hospitality, in the religious domain, includes relating well with the ancestors. It is for this reason that in the Ancient African hospitality, it was customary when drinking the local beer to pour out the last few drops in the calabash for the ancestors. Similarly, it was believed that, when a pot of beer cracks, it was said to be good for the ancestors are eating. ${ }^{10}$ Moeahabo Phillip Moila contends that the Pedi woman will always dish out food for the ancestors when she is cooking. ${ }^{11}$ This is also common even among the Kikuyu, the Giriama, the Digo, the Chonyi, the Kamba and the Taita communities of Kenya. The only difference is that the East African communities have had a habit of pouring anything, including water, tea, or food on the ground before they consume it as a way of seeking blessings from God through the ancestors. In turn, the ancestors are believed to be closer to God than the ordinary people, hence the need to appease them before they consume. This symbolises a harmonious relationship between the living and the living-dead. It can be compared with prayers offered in the modern African Christianity every time before we take meals.

Who are the ancestors? It is the deceased people who become ancestors and still remain part of the community. They are also referred to as the living-dead. Traditionally, as Healey and Sybertz say, the living dead were remembered in the oral tradition for five

\footnotetext{
N Tutu, The words of Desmond Tutu. (London: Hodder and Stoughton, 1989), 71.

HO Mönnig, The Pedi, (Pretoria: L van Schaiks, 1978), 61.

11 Moeahabo Phillip Moila, Challenging Issues in African Christianity. (Pretoria: CB Powell Bible Centre, 2002), 3 .
} 
generations. ${ }^{12}$ Their being remembered or not depend on how much good they had done on earth, especially hospitality to others. For as Dickson points out, "in African thought those who become ancestors must have lived exemplary lives (read hospitable lives - my emphasis); it is not everyone who dies who becomes an ancestor, so that the cult of the dead is not to be equated with that of the ancestors." 13

The questions of ancestry and hospitality are very crucial in Africa. For example, the Fang of Gabon believe that an ancestor passes by in the person of a stranger and, therefore, a stranger should be given a very kind and warm treatment. ${ }^{14}$ Similarly, the Bulsa treat strangers, orphaned, handicapped people, beggars and lepers very well because of their belief that their ancestors visit them in these forms. ${ }^{15}$

Generally, in most African communities, it is believed that unexpected guests are the embodiment of ancestors; hence, they are given the ancestors' food. ${ }^{16}$ In such hospitality, it means communing with ancestors through such impromptu services to guests, hence, maintaining a relationship through the practice of hospitality.

\section{Economic Life}

Secondly, African hospitality is manifested in the economic life; and this involves communal willingness to assist each other. From the ancient times, Africans have displayed their hospitality by co-operating in works such as agricultural work, the building and repair of houses, land cultivation and clearance of bushy areas, hunting, and fishing among others. With regard to the Kikuyu of Kenya, Kenyatta explains that African hospitality depends heavily on industriousness. ${ }^{17}$

By industriousness is meant a quality of being hard-working to promote the economic well being of the community; and at the same time discouraging laziness as the destruction of the community. Kenyatta analyses the type of industries among the Kikuyu of Kenya, most of which were conducted communally as a gesture of hospitality. They include ironwork, hut building, pottery, basket making, skin tanning, musical instruments, and agricultural activities. $^{18}$ The concept of hard-work, therefore, assumes that it is when you are hard working that you will have something to be hospitable with such as food, shelter, clothing and other materials.

In Africa, one cannot be mean with services. For a hospitable person is one who is generous in providing food and shelter for the needy and services for whoever needs help. With regard to the Luo of Western Kenya, Obengo explains that a hospitable and generous person is termed as 'jangwono,' which means 'a gracious person. ${ }^{19}$ This agrees with the Kikuyu community who refer to a hospitable person as 'mutugi' which has two meanings: 'a gracious person' or/and 'a hospitable person.' This shows that the word 'hospitable' is to the Africans; for to be associated with grace, is to be associated with divine name; for God is also described as 'gracious' among the Africans. To be hospitable, therefore, is to

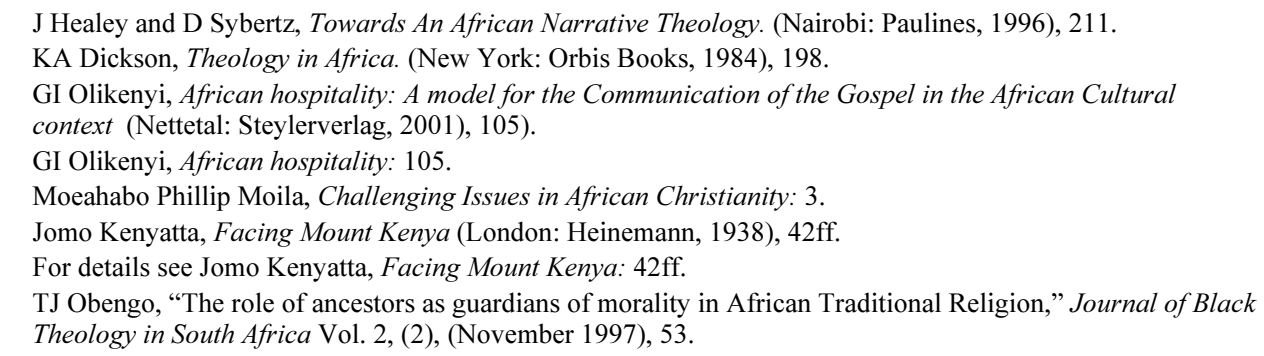


participate in God's gracious acts of doing well to others, including working to assist in improving the economic or social well being of the individual and the society in general.

As Obengo says of the Luo people of Kenya, a sharply contrasting term to hospitality is 'ja wooro' which describes both the greedy and the stingy. ${ }^{20}$ Among the Kikuyu, the vice opposed to generosity and hospitality, which is referred to as ithunu, is almost absolute. Mean or stingy people stand condemned as social outcasts and are believed to be cursed people. In the ancient times, they were highly stigmatised; and were classed with robbers, murderers, prostitutes, witches, sorcerers, corrupt, defrauders and greedy people of the world who are short sighted and lacking in vision. A Kikuyu proverb that says, Mukari aimaga uhuunii saying: "A mean person refuses to serve food to one who has eaten," is used to caution against meanness or being stingy in socio-economic life. It is reminiscent of Christ's words that, "He who saves his life loses it and whosoever looses it finds it" (Mark 8:34-35).

However, African hospitality is dispensed in moderation and in prudence. This is demonstrated by the following proverbs, Utaana muingi uninagira murokerwo ng'ombe saying: "Too much generosity depletes the cows of the one visited in the morning." This Kikuyu proverb cautions against reckless hospitality, otherwise called, in the Bible, prodigality.

Another proverb that cautions on foolish dispensation of hospitality is the Ganda proverb that says: "A visitor is a visitor for several days, and then put the person to work." It agrees with the Swahili proverb, which says, Mgeni siku mbili, siku ya tatu mpe jembe akalime saying: "A visitor is a guest for two days, on the third day, put him or her to work (by giving him or her a hoe)." 21 These proverbs imply that a person is not a visitor forever. At one stage he or she will be accepted as one who now needs to work like the rest to promote the economic well being of the host and the entire community. This proverb was used in Tanzania by President Julius Nyerere, during the Ujamaa policies to discourage laziness among the idlers of Tanzania, and Africa at large, who consumes the sweat of others, like parasites, in the name of going for holidays and other excuses. ${ }^{22}$

Other proverbs that clarify that African hospitality expressed in moderation and in prudence are: Ndugu nyingi ithatagia muhuko saying: "Having too many friends empties one's pockets" (Kikuyu), and Kinandu kia mucii gitihakagwo mugeni saying: "The family oil is not to be used on strangers" (Kikuyu). Thus, while acknowledging the need for hospitality they urge that prudence to be the guide in its practice. It also shows that hospitality is more than welcoming people, for it also means avoiding being misused or being exploited, as the above proverbs have shown.

While acknowledging prudence as the guide in the dispensation of hospitality, many African proverbs tend to caution against the danger of the hosts themselves being impatient with the visitors. This is especially so in our modern economy when people are too busy in this task oriented Africa. In addressing this, the Chewa have a proverb that says: "Treat the visitor well because she/he is like a morning dew which disappears very quickly with the morning sun. ${ }^{, 23}$ It is mainly used when hosts get tired of the visitors and begin to mistreat them.

Mercy Oduyoye quotes Rose-Zoe Obianga who contends that Africans welcomed Europeans and adopted Europeans' values only to find that the element of reciprocity was

\footnotetext{
TJ Obengo, The Role of Ancestors as Guardians of Morality in African Traditional Religion: 57.

J Healey, and D Sybertz, Towards an African Narrative Theology: 172-3.

J Healey, and D Sybertz, Towards an African Narrative Theology: 173.

Interview with Prof Isabel Phiri on $13^{\text {th }}$ September 2003.
} 
missing. ${ }^{24}$ As she further says, Africans resisted this misuse of their hospitality and continue to do so when the outside values are deemed incompatible with African norms. ${ }^{25}$ Oduyoye cites the case of Nyerere of Tanzania who linked hospitality with work and economic productivity: "Treat your guests as guests for two days, and on the third day, give them hoes." 26 That means: "Put them to work doing whatever you do to sustain your hospitality." Thus, hospitality demands that we teach not only life skills but also specifically economic skills in order to prevent dependency and parasitism. All in all, hospitality and generosity are inseparable virtues of a good person in most African traditions.

\section{Social Life}

Thirdly, African hospitality manifests itself through social life, which is also fully permeated by religion. In so doing, it serves the sustenance of a holistic community. ${ }^{27}$ For that reason, activities such as dancing and singing are "perceived as hospitable activities in that they bind the community together." ${ }^{28}$ Africans dance to celebrate every "imaginable situation - joy, grief, love, hate, to bring prosperity, to avert calamity. In addition, singing and joyful conversation enable African people to minimise tensions within enclosed community." 29

Bolaji Idowu observes that:

Songs constitute a rich heritage for the whole of Africa. For Africans are always singing and in their singing and poetry, they express themselves. In this way, all their joys and sorrows, their hopes and fears about the future, find an outlet. Singing is always a vehicle conveying certain sentiments or truths. When songs are connected with rituals they convey the faith of worshippers from the heart-faith in the Deity, belief in and about divinities, assurance and hopes about the present and with regard to the hereafter. ${ }^{30}$

This shows when dance is accompanied by song it is used to express more than just entertainment in that it becomes a manifestation of the feeling of the individual or a group thus communicating their internal sentiments, expectations and aspirations. In so doing, African hospitality is clearly expressed.

And in his theology of reconstruction, Jesse Mugambi cites four cases of 'revival' songs that point to the shape of his proposal for what he calls the 'individual reconstruction.' They include, "Amazing grace, how sweet the sound that saved a wreck like me," "Teach me thy way o Lord," "Take my life and let it be consecrated to thee," and "Just I am without one plea." who is pleading to God (as in Psalms 138, 139, 140, 141-143) or praising God (like in Psalms 145-150) at a personal level - as opposed to communal praise and worship for God. In other words, it is both a prayer and a thanksgiving to God - that directly affects the individual who wants to fellowship with his or her maker. Mugambi's use of hymns to

24 Mercy A Oduyoye, Introducing African Women's Theology. (Sheffield: Sheffield Academic Press, 2001), 94-5.

25 The ongoing debate in the Anglican Church on whether to accept homosexual clergy can illustrate this point in that the African churches have vehemently refused to accept the consecration of homosexual Bishops in both Europe and North America as they contend it as against African norms and Biblical traditions.

26 Mercy A Oduyoye, Introducing African Women's Theology: 95.

7 Moeahabo Phillip Moila, Challenging Issues in African Christianity: 3.

Moeahabo Phillip Moila, Challenging Issues in African Christianity: 3.

SA Thorpe, African Traditional Religion. (Pretoria: University of South Africa, 1991), 116.

EB Idowu, African Traditional Religion: A Definition, (London: S.C.M Press, 1973), 84.

1 JNK Mugambi, From Liberation to Reconstruction: $15 \mathrm{f}$. 
drive home his theme of reconstruction is more of a continuation from his earlier works, in his book, African Christian Theology: An Introduction ${ }^{32}$ where he equally uses the same Hymn-Biblical-text method to drive home the theme of liberation.

Jesse Mugambi's approach of driving home his points by using the above method (Hymn-Biblical-text) is within the framework of the African ethos where important issues (or sometimes people who are considered as dignified members of the society) must be 'escorted' with a memorable and/or relevant song - a fact which gives authenticity to his works, considering that his primary audience is the African context. For whether in the church, in politics, in education or in social life, songs have not lost their value in Africa. ${ }^{33}$ Chima stresses this point when he says, "whether songs are used in rites of passage (birth, puberty, initiation, marriage, etc) or in the various human activities (work, hunting, harvesting, etc.) and whether their contents refer to birds, animals, seasons or humans, songs have human life, behaviour and relationships as their main interest." 34 This shows that songs (or hymns), in Africa, are not just a concordance of notes and voices, but each song expresses a general mood and meaning of a given situation.

While acknowledging the idea of introducing hymns as a vehicle for communicating a theology of reconstruction, I cannot, however, fail to be critical of Jesse Mugambi's failure to use the African traditional songs as examples. In fact, four samples of hymns that he has outlined in his From liberation to reconstruction 1995, were composed before the $20^{\text {th }}$ century by the revivalists in Europe. A reference to Charlotte Elliot's song, "Just as I am without one plea, but that thy blood was shed for me, And that thou biddst me come to Thee, O Lamb of God, I come," as quoted in Christian Praise (London: Tyndale Press 1957), Hymn 204, does not help matters. Nevertheless, songs and dances are powerful expressions of African hospitality; and cannot be wished away when discussing African hospitality.

Another common expression of our African hospitality is through community drama. As Njino notes, drama is a play performed by actors based on poetry, legends, myths, past or present events, for either entertainment or teaching moral and social lessons. ${ }^{35}$ Thus, it is closely related to song and dance. From time immemorial, it has been used to mock evil or to mock ungodly behaviours, to caricature, to satirize and to conscientize the society on what ought to be taken seriously ${ }^{36}$ It is also used to mock any abuse of African hospitality and to praise and to educate people on hospitality; and as we move on with the $21^{\text {st }}$ century, it will be more useful in the African Church.

Song, dance and drama are accompanied by instruments such as the guitar (which is not originally African but a Western adaptation), the Kayamba (an African musical instrument) and the drum. ${ }^{37}$ In general, various instruments communicate particular messages. A good example is a drum. Depending on the size of the drum, it was used to send a message of death and mourning. In other words, the sound it produces matters much. It also communicates a message of joy and celebration. It is also used as a call signal for intervillage communication. This is especially done in times of war or any other urgency. ${ }^{38}$ In

32 JNK Mugambi, African Christian Theology: An Introduction ((Nairobi: Heinemann, 1989), 10-11).

33 Julius Gathogo, The Truth About African Hospitality: Is there Hope for Africa? (Mombasa: The Salt, 2001), 81-82.

34 A Chima, "Story and African Theology," AFER Vol. 26, (1994): 60.

5 J Njino, Communicating the Gospel Message in Africa Today (AMECEA: Gaba, 1992), 7.

6 J Njino, Communicating the Gospel Message in Africa Today: 8.

7 This is an observation made through participatory observation in both the Kenyan and South African context.

8 J Njino, Communicating the Gospel Message in Africa Today: 10. 
any case, the Chiefs barazas (meetings) in the ancient Africa relied on drums to announce or call upon the people to assemble. ${ }^{39}$ Interestingly, many African radio and television stations have adopted the use of the drums to announce the different programmes. Good examples include: The national television and Radio in Tanzania and Nation Television of Kenya - all in East Africa. ${ }^{40}$

In other words, hospitality, in the social sphere, plays the role of the life affirming and life sustaining. For indeed an individual is never alone. The Kikuyu of Kenya have a saying (proverb) that, muria wiki akuaga wiki saying: "He who eats alone dies alone." The Kamba of Kenya also has the same saying as Mbiti tells us. Mbiti further contends that the proverb is used to highlight the value of sharing both joy (food) and sorrow (death). He further says that if there is no fellowship, there is no sharing of food during one's life. This follows that there will be no sharing of grief and bereavement at one's funeral. ${ }^{41}$ In this regard, hospitality means more than sharing of experiences by members of a group. For indeed hospitality eradicates loneliness. This view is affirmed by a saying among the Zulu that, "individuals cannot exist alone. They are because they belong." ${ }^{42}$ Moila builds this further when he argues that any disruption of the well-being of a community calls for the members of a societal group to sit down together and share a common meal. ${ }^{43}$

After borrowing heavily from the many African societies such as Asu of Tanzania, the Nupe of Nigeria, the Efe (Pygmy) of the Democratic Republic of Congo, and the Fulani of West Africa, Mbiti aptly summarises the meaning of the ideal hospitality in Africa:

It can be made more palatable to avoid the state in which 'a person who eats alone dies alone'. If we eat together, we can also happily die together - whether according to African Religion, Christianity, or other religious traditions. There is in each person something exceedingly valuable, wonderful, and indestructible... ${ }^{44}$

In the social domain, African hospitality has a lot to do with material support on auspicious occasions such as betrothals, marriages, initiations, fundraising for medical bills, mourning for the dead, burials, education of children and social gatherings. In such situations, villagers pour in without waiting for invitation cards or any formal invitation. ${ }^{45}$ This is to do with the African communality where one person's happiness is happiness for all and one person's sorrow is sorrow for all.

In the political domain, Ubuntu philosophy would best illustrate African hospitality. Augustine Shutte observes that the concept of Ubuntu was developed over many centuries in traditional African culture. As he further says, this culture was pre-literate, pre-scientific and pre-industrial. ${ }^{46}$ This concept of Ubuntu was originally expressed in the songs and stories, the customs and the institutions of the people. As will be demonstrated, in this section, Ubuntu is an expression that shows the essence of African culture, a culture which

39 Julius Gathogo, The Truth About African Hospitality: Is there Hope for Africa? (Mombasa: The Salt, 2001), 82 .

40 These examples can be noted by listening to the Radio and Television Stations.

41 JS Mbiti, "A person who Eats Alone Dies Alone: Death as a Point of Dialogue Between African Religion and Christianity" in Mwakabana, HAO (ed.) Crises of Life in African Religion and Christianity (Geneva: The Lutheran World Federation, 2002), 83.

42 Moeahabo Phillip Moila, Challenging Issues in African Christianity: 4.

43 Moeahabo Phillip Moila, Challenging Issues in African Christianity: 4.

44 JS Mbiti, "“A person who Eats Alone Dies Alone”: 83.

45 This paragraph is partly informed by research before 2001 when I was working on my book: The Truth about African Hospitality: Is There Hope for Africa? (Mombasa: The Salt production).

46 Augustine Shutte, Ubuntu: An Ethic for a New South Africa. (Pietermaritzburg: Cluster Publications, 2001 ), 9. 
is initially perceived as pure unadulterated form, untarnished by Western cultural 'corruption' or market economical drives and so on.

Ubuntu is a Zulu and Xhosa word for humanness and encompasses all that makes one human; in Setswana it is botho; in Shona unhu or ubuntu; Venda vhuthu; Kikuyu umundu; and in Kiswahili $u t u$, to name a few. A related Swahili concept Ujamaa (familihood) was translated into a political philosophy by Julius Nyerere during his presidency (19611985). ${ }^{47}$ Often, Ubuntu is described in a broad way that embraces human life in an existential way. In particular:

Ubuntu includes all the qualities and traits which go into making a person fully human

and include the willingness and ability to respond positively to the Creator. ${ }^{48}$

The strength of Ubuntu, as an African philosophy, in our modern African society, is seen in Shutte's contention that since some "of the old customs would be a betrayal" to the spirit of Ubuntu in our contemporary society, it is important for us (in Africa) to find a way of living Ubuntu in a society where the dominant cultures are both European and African; and where many other cultures from other parts of the world exist together. ${ }^{49}$ And in view of this, it is worthwhile to consider that some of the customs that can be a betrayal today includes the saying that "we are the people and others (referring to other communities) are not." It would amount to adding an insult to an injury if black Africans target one another alongside ethnic lines. Similarly, there is a need to acknowledge that Africa is like "my father's house in which there are many mansions" ( $c f$. John 14) - which simply means that Africa is a home for various categories of God's children who need to appreciate one another. Failure to acknowledge this reality would encourage unnecessary and uncalled-for tensions. By acknowledging and appreciating the diversity of the racial or the ethnic realities of Africa, Africa would prove to be the shinning star of the world as it would set good examples of peaceful co-existence, especially in the era of globalisation.

Another distinctive quality of the Ubuntu philosophy is the African emphasis on consensus. In other words, Ubuntu underscores the importance of agreement or consensus. Indeed, the African traditional culture has, seemingly, an almost infinite capacity for the pursuit of consensus and reconciliation. ${ }^{50}$ Democracy in the African way does not simply boil down to majority rule since it operates in the form of discussions geared towards consensus. This view is clearly captured by Jesse Mugambi when he says that: "The traditional court would appreciate the views of every participant, and weigh the opinions of everyone irrespective of social status." ${ }^{, 51}$ Equally, decisions are reached through consensus, as there is no voting. Whenever there are "irreconcilable differences, decision is postponed until a consensus emerges." ${ }^{, 52}$ This important aim of consensus building rather than dividing the people along the lines of "winners versus losers" is expressed by words like twi hamwe (Kikuyu for "we are together"); tuko nawewe (Swahili for "you are not alone"); and Simunye (a Zulu word for "we are one"). These African phrases point to the fact that, "unity is strength"; and they agree with the slogans such as "an injury to one is an injury to all."

47 See HS Olson, "A Seamless Garment, African Understanding of Wholeness," Currents in Theology and Mission 18, (4), (1991): 275.

48 E Baartman, "The Religious Needs of Children and Young People. A Panel Discussion,” Journal of Theology for Southern Africa, 33 (1980): 77.

49 Augustine Shutte, Ubuntu: An Ethic for a New South Africa: 10.

$50 \mathrm{~J}$ Teffo, The Concept of Ubuntu as a Cohesive Moral Value. (Pretoria: Ubuntu School of Philosophy, 1994), 4.

51 Jesse Mugambi, From Liberation to Reconstruction: Africa after the Cold War (Nairobi: EAEP, 1995$), 132$.

52 Jesse Mugambi. From Liberation to Reconstruction: 132. 
Despite Ubuntu's articulation of important values such as respect, human dignity and compassion, it can, however, be exploited to enforce group solidarity and therefore fail to safeguard the rights and opinions of individuals and the minority (though this is a Western concept). True Ubuntu, however, requires an authentic respect for individual rights and values and an honest appreciation of diversities amongst the people. In view of this, Ubuntu illustrates the African hospitality and homogeneity that can be exploited for the good of Africa of the $21^{\text {st }}$ century.

As spiritual foundation of African societies, Ubuntu is a unifying vision or worldview enshrined in the Zulu Maxim Umuntu ngumuntu ngabantu, that is, "a person is a person through other persons." 53 This Ubuntu concept is also found in other African communities, even though there are different vocabularies and phrases that are used to describe it; and it will suffice to illustrate it by citing a few examples. The Kikuyu idiom, which says that: Mundu ni mundu ni undu wa andu, just as the Swahili have: Mtu ni mtu kwasababu ya watu which means that: "A human being is a person because of the other people." The same can be said of the Sotho whose idiom says that: Mothe ke motho ka batho with a similar translation to those of other African communities. This African aphorism articulates a basic respect and compassion for others, as its bottom line. It can be interpreted as an ideal way of being an African and/or as a rule of conduct or social ethic. It both describes human being as 'being-with-others' and prescribes what 'being-with-others' should be all about. As such, Ubuntu has socio-religious commitment in the welfare of fellow human beings that is manifestly African in essence. Indeed, while Western humanism tends to underestimate or even deny the importance of religious beliefs, Ubuntu or African humanism, is resiliently religious. As a concept that is well rooted in the African hospitality, Ubuntu nevertheless deserves to be revitalised in the hearts and minds of the African people so that its ethos can be truly one of the major contributions that African philosophy can bequeath other philosophies of the world.

As S Maphisa argues, South Africans are slowly re-discovering their common humanity. He says:

Gone are the days when people were stripped of their dignity (ubuntu) through harsh

laws: Gone are the days when people had to use ubulwane (that is, animal like behaviour) to uphold or reinforce those laws. I suggest that the transformation of an apartheid South Africa into a democracy is a re-discovery of $u$ buntu. ${ }^{54}$

M Mahamba agrees with Maphisa's observation and even describes Ubuntu in terms reminiscent of the concept of 'spirit' in the Old Testament; for this, in essence, distinguishes human life from animal life. ${ }^{55}$ It also agrees with J. Teffo's when he contends that Ubuntu serves, pervasively, as a cohesive moral value in the face of adversity. For although the policy of apartheid greatly damaged the overwhelming majority of black South Africans:

...there is no lust for vengeance, no apocalyptic retribution... A yearning for justice, yes, and for release from poverty and oppression, but no dream of themselves becoming the persecutors, of turning the tables of apartheid on White South Africans... The ethos of

\footnotetext{
Augustine Shutte, Ubuntu: An Ethic for a New South Africa: 46.

34 S Maphisa, Man in constant search of Ubuntu: A Dramatist's Obsession (Pretoria: Ubuntu School of Philosophy, 1994), 8.

55 M Mahamba, "Ubuntu and Democracy," Challenge (June/July 1993): 7.
} 
Ubuntu ... is one single gift that African philosophy can bequeath on other philosophies of the world... ${ }^{56}$

An acknowledgement that every culture has its dark and dangerous side as well, helps the Ubuntu philosophy today to absorb the strength of the European cultural emphasis on freedom in the individual idea of choice; while at the same time building on the strength of the African cultural emphasis on the idea of communality - that is, "persons depend on other persons to be persons." In turn, both African and European cultural emphasis should seek to learn from Christ's ideal hospitality which went beyond racial, ethnic, status, gender, area of origin or any prejudice. This acknowledgement helps in producing a synthesis that is true to the ideal way of modern living. It also encourages us to prioritise the needs of our fellow members of humanity.

On the other hand, it is critical to underline the fact that in our modern times Ubuntu is being undermined by the violent ethnic and political conflicts that have plagued tropical Africa. In view of this, the application of the philosophy of Ubuntu to the South African situation may look too abstract, or rather idealistic, in the sense that it may be seen as if it has portrayed a heaven-on-earth kind of situation. For if such philosophy is applicable, how can one explain the cases of rape, robbery and insecurity in South Africa? How can one explain the re-emerging negative effect of tribal nationalisms (as was, at one time, propounded by Mongosuthu Buthelezi of the Inkatha Freedom Party in the 1990s and its consequent fundamentalist attitude) in the political domain even after it had died with the demise of apartheid? And even within the rest of Africa, how can one explain the spirit of Ubuntu amidst the Rwandan genocide of 1994, the religious clashes between Muslims and Christians in Nigeria, the current Somalia conflict, the Liberian genocide, the political assassinations in post-colonial Africa and tribalism which is the single major ideological threat facing Africa following the demise of apartheid? In a continent, plagued by war, hunger, genocide and disease, can Ubuntu be seen as the panacea for all these challenges? Conversely, it can be argued that these concerns can be addressed effectively by first adhering, strictly, to the ancient ideals of African hospitality, which portrays every 'neighbour' as part of the extended family, and hence treats him or her with compassion and understanding.

\section{Conclusion}

As noted in our introduction, the subject under discussion is an ambitious one. Nevertheless, I attempted to survey some socio-religious manifestations of African hospitality by highlighting certain themes and sub-themes that are crucial in providing an introduction on the study of African hospitality. Consequently, I have sketched an outline of the above elements that have driven us to see the 'agenda' of African hospitality as one which needs to be revisited in the post Cold War Africa - as it builds on reconciliation and interdependence. It also builds on the need of refocusing on the process of psychosocial reconstruction of our consciousness and the need to build on the productive past as we focus on the future of the post Cold War Africa. All in all, the study has sought to demonstrate that African cultural resources are crucial in the post Cold War reconstruction of Africa. Additionally, these African resources have something to bequeath to the rest of the world.

56 J Teffo, The Concept of Ubuntu as a Cohesive Moral Value (Pretoria: Ubuntu School of Philosophy, 1994), 5. 
And in doing a theology of reconstruction, which is post-exilic, inclusive as opposed to exclusive, future sensitive and inspired by Nehemiah's role in the rebuilding of the wall of Jerusalem in $538 \mathrm{BCE}$, the concept of hospitality cannot be ignored. I consider it as the theology of the 21 st century CE. Its approaches and methodologies will include: contextual theologising, a cultural-anthropological inquiry, philosophical inquiry, a historical inquiry, a critical re-evaluation of Biblical themes of liberation and salvation, a re-reading of the text of Ezra-Nehemiah with the post Cold War Africa in mind, a re-reading of the Sermon on the Mount (Matt.5-7), a multi-disciplinary approach, an ecumenical and an all-inclusive approach, and a re-reading of the New Testament in general with a reconstructive bias. Thus, African Christian theology has to give adequate attention to the study of some rich cultural concepts such as Africa hospitality - as it has previously done with the study of African indigenous religion. This is, indeed, an ideal way of authenticating and reconstructing African Christianity today. 